\title{
PERKEMBANGAN HADIS DI INDONESIA PADA ABAD XX
}

\author{
Badri Khaeruman \\ Dosen Fakultas Ushuluddin UIN Sunan Gunung Djati Bandung \\ Jl. AH. Nasution No. 105, Bandung, Indonesia \\ E-Mail: Badrikhaeruman@gmail.com
}

\begin{abstract}
In searching of history of tradition in Indonesia can be said begun growing in recent years. Although this study has not been adequate but increasingly snow along the archipelago Islamic discourse that touches various branches of Islam in Indonesia. In addition to the reason that the study of hadith is not as intense as other studies in Islam, such as AI-Qur'an, fiqh, morals and so on, the study of hadith can be said to be growing very slowly. This can be measured by the fact that the 'scholars Nusantara started writing in tradition since the 17th century. This article will try to review the development of the study of Hadith in Indonesia in 20 th century that several works written by scholars of hadith or tradition can be said observers in the archipelago. Whether it works or original manuscripts speak Arabic and also there are some Works that are adaptations of the work of others.
\end{abstract}

Keywords: Hadis; Indonesia; Study; Period; Nusantara.

\begin{abstract}
Abstrak
Penelusuran sejarah hadis di Indonesia dapat dikatakan mulai berkembang pada bcbcmpa uhun terakhir ini. Walaupun belum memadai namun kajian ini scmakin membola salju seiriing Wacana Islam Nusantara yang menyentuh berbagai cabang ilmu keislaman di Indonesia Selain karena alasan bahwa kajian hadis tidak seintens kajian di keislaman yang lain, seperti a1-Qur'an, fiqh, akhlak dan scbagainya, kajian hadis bisa dikatakan berkembang sangat lambat. Hal dapat diukur melalui kenyataan bahwa para ulama Nusantara mulai menulis di bidang hadis sejak abad ke-17. Artikel ini akan mencoba mengulas perkembangan study hadis di Indones pada abad ke dua puluh yang melibatkan beberapa karya yang dibahas oleh para ahli hadis atau bisa dikatakan pemerhati hadis di Nusantara. Baik itu kurya- karya atau naskah asli berbahasa Arab dan juga ada beberapa karya yang bcrsit'at sudurun terhadap karya lainnya
\end{abstract}

Kata Kunci: Hadis; Indonesia; Kajian; Nusantara; Periode.

\section{A. PENDAHULUAN}

Guna memberikan landasan teoretis dalam memahami perkembangan Hadis di Indonesia pada Abad XX, ada baiknya jika penulis terlebih dahalu memberikan ilustrasi tentang perkembangan Islam di Indonesia itu sendiri menjelang Abad tersebut.Karena hal ini berkaitan erat dengan kajian tentang perkembangan Hadis di Indonesia sebagai sumber ajaran Islam yang kedua setelah alQur'an, baik itu berkaitan erat dengan pengembangan keilmuannya maupun sisi aplikasi petunjuknya.

Penelusuran sejarah Islam di Indonesia pada masa itu, secara sosiologis berkaitan erat dengan munculnya gerakan pembaruan pemikiran Islam yang dipelopori oleh para alumni Timur Tengah, sebagai tempat asal munculnya gerakan tersebut.Namun sejarah pembaruan pemikiran Islam di Indonesia, berbeda dengan pembaruan di dunia Islam lainnya.Pembaruan di Indonesia lebih merupakan sejarah organisasi sosial keagamaan. Sedangkan di negeri lain lebih terpusat pada pribadi-pribadi tertentu. Semangat kaum pembaru ini muncul karena dipengaruhi oleh ide dan gerakan pembaruan yang telah berkembang di dunia Islam, khususnya yang terjadi di kawasan Timur Tengah, seperti gerakan Wahabi di Saudi Arabia dan gerakan pembaruan Muhammad Abduh di Mesir. Namun jauh sebelum Muhammad Ibn Abdul Wahab (1703-1778), Jamaluddin al-Afghani (1839-1897), Muhammad Abduh (1845-1905) dan Muhammad Rasyid Ridha (1856-1935) melancarkan gerakan pembaruan Islam, adalah Ibn Taimiyah (1262-1318) yang kemudian diteruskan oleh muridnya, Ibn Qayyim al-Jawziyah (1292-1350), telah 
merintis akar pembaruan Islam, yakni dengan gagasan utamanya, mengembalikan umat Islam kepada ajaran yang sesuai dengan alQur'an dan al-Sunnah, yang kemudian menjadi semboyan kalangan Islam modernis di Indonesia tersebut.

Ibn Taimiyah, melalui pikiran-pikiran kritis maupun kritiknya terhadap prilaku keagamaan masyarakat yang dianggap jauh menyimpang dari ajaran al-Qur'an dan alSunnah, menyatakan:

"Bahwa Rasulullah SAW telah menjelaskan seluruh segi agama baik prinsip-prinsipnya maupun cabang-cabangnya baik segi batinnya maupun lahirnya, baik segi ilmu maupun amalnya.Sesungguhnya prinsip ini adalah pangkal prinsip-prinsip ilmu dan iman.Barangsiapa berpegang Iebih kuat pada prinsip itu maka ia lebih berhak alas kebenaran, baik dalam segi ilmu maupun segi amal..."1

Ibn Taimiyah bahkan mengingatkan pula perlunya berhati-hati terhadap berbagai pendapat ulama tentang agama, ia dengan tegas menyatakan:

"Banyak di antara mutrahid di kalangan salafdan khalaf yang telah berpengertian dan melakukan haI-hal yang sebenarnya merupakan bid 'ah terapi mereka tidak menyadari bahwa hal itu bid 'ah. Boleh jadi karena Hadis-hadis lamah (dha 'if) yang mereka sangka shahih, alau karena ayarayat Yang mereka pahami daripadanya sesuatu yang tidak menjadi maksudnya, atau karena suatu pendapat pribadi (ra'yu) yang dipegangnya padahal untuk masalah bersangkutan terdapal nash-nash yang tidak sampai kepada mereka ${ }^{2}$

Demikian sebagian kecil pemikiran Ibn Taimiyah mengenai apa yang kemudian disebut sebagai gagasan keharusan adanya pembaruan pemikiran Islam. Pernyataanpernyataan senada, kemudian banyak ditemukan dalam pemikiran keagamaan muridnya, Ibnu Qayyim al-Jawziyah. Muhammad Abduh dan Muhmmad Rasyid Ridha. Bahkan benang merah pemikiran

1 Nurchalis Madjid, Khazanah Inlelaktual Islam (Jakaarta: Bulan Bintang, 1984), p. 247.

${ }^{2}$ Madjid, p. 290. sepeni itu, jika dilacak lebih jauh, juga merupakan sikap utama Imam Ahmad Ibn Hanbal, yang lebih mengutamakan Petunjuk Hadis ketimbang rasionalitas produk pikiran manusia.

Gagasan Pembaruan Islam yang dirintis oleh Ibn Taimiyyah ini telah masuk ke Indonesia sekitar tahun 1802. Menurut M. Muljadi Djojomartono dkk, dalam "Dunia Baru Islam"3 dinyatakan bahwa bersamaan dengan pulangnya Haji Miskin dan temantemannya dari menunaikan haji dan setelah bermukim beberapa tahun di Makkah, maka Wahhabisme pun disebarkan di Minangkabau oleh Haji Miskin dan kawankawannya yang terkenal dengan julukan Harimau nan Salapan. Mereka adalah; Tuanku Haji Miskin, Tuanku di Kubu Sanang, Tuanku di Koto Ambalau, Tuanku di Ladang Lawas, Tuanku di Padang Luar, Tuanku di Galung, Tuanku di Lubuk Aur, Tuanku Nan Renceh.Mereka dikenal pula sebagai tokoh-tokoh Paderi, yakni sebutan bagi yang tidak mengenal ajaran ini, karena berpakaian mereka selalu berpakian serba putih.

Paham ini mendapat tantangan keras dari masyarakat setempat yang berpandangan Islam tradisional, sehingga menimbulkan pertikaian di antara mereka.Akibat pertikaian itu sehingga timbul perang Paderi (17851838). Setelah Belanda ikut campur dalam pertikaian tersebut, bentuk peperangan pun berubah, yang tadinya antara golongan Paderi, yang dikenal dengan kaum muda, dengan golongan tradisional, dikenal dengan kaum tua, kemudian bersatu melawan penguasa kolonial. ${ }^{4}$

${ }^{3}$ L. Stoddard, Dunia Baru Islam, trans. by H. M. Muljadi Djojomartono (Jakaarta: Panitia Penerbit, 1966), pp. 302-3.Tulisan ini bukan berasal dari Lopthrop Stoddard, melainkan merupakan bab tambahan yang dilakukan oleh penerjemahan atas perintah Soekarno.

4 Uraian ini telah dijelaskan pula pada bab pendahuluan. Menurut Mahmud Yunus, gerakan Paderi ini mirip gerakan Wahhabiah di Arab Saudi. karena gerakan ini memberantas sikap-sikap masyarakat yang dianggap menyimpang dari ajaran Islam, dengan cara kekerasan. Lihat, Sejarah Islam Di 
Meskipun dalam perang Paderi ini, Belanda mampu mengikis habis perlawanan kaum Paderi,namun paham pembaruan yang disebarkannya tidak lenyap. Bahkan timbul tokoh-tokoh baru.Mereka terus menyebarkan ide pembaruan. Tercatat misalnya, Syekh Muhammad Abdullah Ahmad (1878-1933), Syekh Haji Abdul Karim Amrullah (18791945), Syekh Muhammad Jamil Jambek (1860-1947), Syekh Muhammad Ibrahim Musa Parabek (1884-963), Syekh Haji Muhammad Thaib Umar (1874-1920) dan lain-lain.

Kemudian pada tahun 1918, atas inisiatif murid-murid syeikh Abdul Karim Amarullah didirikan sebuah perkumpulan yang bernama "Sumatera Thawalib". Setahun kemudian yaitu pada tahun 1919, atas inisiatif Zainuddin Labai didirikan pula sebuah organisasi khusus untuk kalangan guru yang diberi nama Persatuan Guru-guru Agama Islam (PGAI). ${ }^{5}$

Adapun gerakan pembaruan di tanah Jawa dipelopori oleh KH.Ahmad Dahlan dengan mendirikan Muhammadiyah pada tahun 1912 di Yogyakarta.Organisasi ini bertujuan ingin memajukan pendidikan dan ilmu pengetahuan di Indonesia berdasarkan ajaran Islam serta meningkatkan kehidupan beragama di kalangan anggotanya ${ }^{6}$ Selain KH. Ahmad Dahlan dan Muhammadiyahnya, ada tokoh lain yang cukup berperan dalam pembaruan Islam di pulau Jawa, yaitu syeikh Ahmad Soorkati berasal dari Sudan, ia melancarkan pembaruannya dalam organisasi Jami'at Khair, ${ }^{7}$ yang kemudian pada tahun 1913 mendirikan organisasi baru dengan diberi nama al-Irsyad. Seementara di Bandung, H. Zamzam bersama H. Muhmmad

Minangkabau (Sumatera Barat) (Jakarta: Tintamas, 1961), pp. 23-27.

5 Hamka, Pengaruh Muhammad Abduh Di Indonesia (Jakarta: Tintamas, 1961), pp. 10-14.

6 G.F. Fijper, Baberapa Studi Tentang Sejarah Islam Di Indonesia 1900-1950, trans. by Tudjimah dan Yessy'Agustin (Jakarta: UI Press, 1984), p. 108.

${ }^{7}$ Jami'at Khair adalah organisasi masyarakat Arab yang didirikan pada tahun 1905 di Jakarta.Fijper, p. 15. buku di atas, jika dilihat dari gerakanya tampak sangat modem. Namun masih tradisional dari segi pemahaman keagamaannva.
Yunus, pada tahun 1923 mendirikan Persatuan Islam.

Menurut Deliar N0er, ${ }^{8}$ yang membedakan Islam Tradisional dan Islam Modernis sekurang-kurangnya dari tiga aspek:

Pertama, semangat pemurnian ajaran. Semangat inilah yang telah menumbuhkan upaya-upaya yang tak kenal lelah dari Islam modernis untuk membersihkan ajaran Islam dari apa yang mereka sebut sebagai bid 'ah, Takhayul dan khurafat. Pada perkembangan selanjutnya, upaya pemurnian yang dilakukan Islam modernis ini mendapat reaksi keras pula dari komunitas-komunitas muslimlainnya, yang kemudian memperoleh pijakannya dalam gerakan-gerakan Islam Tradisional. Mereka misalnya, menyebut gerakan Islam modernis itu sebagai agama baru.Sebagai ungkapan penolakan.

Kedua, sikap terhadap tradisi bermadzhab, khususnya dalam bidang fiqh, yang kemudian menimbulkan perselisihan di sekitar masalah khilafiyah dan masalah taqlid.Islam Modernis menggugat tradisi ini, sementara Islam Tradisional mempertahankannya. Pembicaraan masalah khilafiyah seringkali meruncing karena bercampur dengan kepentingan politik sesudah kedua pihak menemukan saluran masing-masing dalam dunia politik.

Ketiga, sikap terhadap perubahan dan rasionalitas.Secara umum Islam tradisionalis digambarkan sebagai kurang menyukai pembahan dan lebih cenderung mempertahankan kebiasaan yang telah lama dianut, sementara Islam modernis sebaliknya, yang menghendaki pembaruan-pembaruan. Hal ini antara lain tercermin dalam lembagalembaga pendidikan pesantren yang dipertahankan oleh lslam tradisionalis sebagai model. Sementara Islam modernis memilih pesantren dengan sistem sekolah (klasikal) yang di Indonesia telah dirintis oleh pemerintah kolonial Belanda.Pesantren tradisional dipandang kaum modernis sebagai sistem pendidikan yang tidak efektif dan efisien dan lebih dariitu tidak

8 Deliar Noer, Gerakan Modern Islam Di Indonesia 1900-I942 (Jakarta: LP3ES, 1980), p. 36. 
memberikan kesempatan berkembangnya aspek rasionalitas di kalangan santri. ${ }^{9}$

Ketiga aspek di atas, kemudian memperoleh bentuknya yang lebih permanen sebagai usaha memurnikan ajaran Islam, yaitu dengan jargon "Kembali kepada Alqur 'an dan al-Sunnah", yang dikenal merupakan semboyan Persatuan Islam.

Itu pula sebabnya, mengapa NU, yang berdiri pada tahun I926 dan al-Jami'atul Wasliyah yang berdiri pada tahun 1930, terlambat didirikan, dibanding Muhammadiyah yang berdiri pada tahun I912, al-Irsyad berdiri pada tahun 1913 dan Persatuan Islam berdiri pada tahun 1923.

Salah satu alasan yang cukup bisa diterima, berdirinya NU dan aliran-aliran Islam tradisionalis sejenisnya, merupakan sikap atas adanya aksi pembaruan Islam di Indonesia. Hal ini diungkapkanpula secara gamlang oleh salah seorang tokoh NU dari Pesantren Tebuireng Jombang, Muhammad Ishom Hadzik dalam salah satu tulisannya, yang menyatakan:

"Ketika dilahirkan pada lahun 1926 NU bukanlah organisasi politik (orpol), tetapi organisasi kemasyarakatan (ormas yang didasarkan ikatan keagamaan yang disimbolkan tali Allah (Hablun Minallah) yang mengitari dunia.Kelahirannya didorong terutama oleh dua keinginan. Pertama keinginan unruk mempertahankan pilar ideologi kaum muslim tradisional yang mulai diguncang pengaruh kaum modernis yang lebih dahulu berdiri. Dan kedua tekad unluk membela eksistensi umat Islam dari penindasan kolonial". ${ }^{10}$

Jadi, fenomena Islam Indonesia menjelang Abad XX benar-benar sangat tradisional, dan pemikiran keislaman yang tradisional itu tentu saja menolak hal-hal yang sifatnya baru, yang tidak ada sebelumnya. Kaum tradisional, misalnya, menolak mentahmentah al-Qur'an diterjemahkan kedalam bahasa setempat atau bahasa Indonesia.

\footnotetext{
9 Penjelasan Deliar Noer tersebut di atas, dikembangkan oleh Imam Thalkhah dan Abdul Aziz., Deliar Noer, Gerakan Islam Kontemporer Di Indonesia (Jakarta: Pustaka Firdaus, 1994), pp. 3-5.

${ }^{10}$ (Fijper 108)
}

Demikian juga Hadis Nabi.Karena tindakan itu dianggap oleh mereka sebagai tindakan yang menyimpang dari tradisi mereka.Khutbah Jum'at dilarang memakai bahasa daerah, harus dengan bahasa aslinya yaitu bahasa Arab. Dan kaum tradisional juga melarang sekolah atau pesantren dalam proses belajar-mengajar memakai sistem klasikal. Karena sistem ini merupakan warisan Belanda. ${ }^{11}$

\section{B. PEMBAHASAN}

Kitab Perkembangan keagamaan Islam Indonesia seperti dipaparkan di muka, tentu membawa konsekuensi logis terhadap perkembangan hadis itu sendiri, yaitu berkembang melalui proses yang alamiah sesuai dengan dinamika keagamaan Islam yang hidup pada masa itu. Jika perkembangan keislaman itu berproses secara tradisional, maka perkembangan hadis itupun tidak jauh dari prinsip-prinsip tradisional pula.Demikian pula, jika perkembangan keislaman itu berubah, maka diduga kuat perkembangan hadis itupun ikut berubah.

Sebagaimana diketahui, bahwa pada abad $X X$ Islam di Indonesia mengalami pembahan, yaitu dengan masuknya paham pembaman pemikiran keislaman, maka konsekuensinya pada perkembangan hadis pun bisa diduga, yakni selangkah lebih maju dari proses awal yang tradisional itu. Namun demikian, sebagaimana diketahui pula bahwa tidak semua umat Islam Indonesia menerima kemunculan paham pembaruan itu, maka tentu saja berdampak kuat pula terhadap perkembangan hadis itu sendiri.Dengan demikian, prospek perkembangan hadis di Indonesia itu berjalan menuju dua arah, yang satu mempertahankan ciri-ciri tradisional, dan yang satu lagi berkembang dengan memanfaatkan situasi kemodernan.Walaupun kemudian pada suatu kurun waktu tertentu misalnya dewasa ini, tidak lagi mempersoalkan ciri khas masing-masing

11 Karel A. Steennbrink, Pesantren Madrasah Sekolah Pendidikan Islam Dalam Kurun Modern (Jakarta: LP3ES, 1994). 
dalam mengembangkan (pemahaman) hadis maupun ilmu hadis.

Ciri kultural dan modernis di atas, tampaknya paling tepat jika dipakai untuk memetakan perkembangan hadis di Indonesia, yang diletakkan dalam dua periodisasi, yaitu periode penyebaran hadis dan periode berikutnya adalah penerjemahkan hadis dan pengembangan ilmu hadis.

\section{Periode Penyebaran Hadits di Indonesia pada Kurun Awal}

Sebagaimana telah dijelaskan pada bagian pendahuluan makalah ini, bahwa fenomena keagamaan Islam Indonesia pada awal abad $\mathrm{XX}$ itu sangat tradisional.Kondisi ini tentu saja membawa konsekuensi logis terhadap penyebaran hadis itu sendiri pada masa itu, yang tidak ada perubahan yang berarti dari masa sebelumnya. Hadis-hadis diduga kuat disebarkan baik melalui lembaga pendidikan formal (baca: pesantren) maupun non-formal seperti ceramah atau pengajian melalui pengutipan langsung dari kitab yang berbahasa Arab. Namun umumnya bukan khusus kitab hadis melainkan kitab fiqh.Hal ini bisa dimengerti karena dalam fiqh terdapat hadis sebagai sumber fiqh itu sendiri. Di lain pihak, budaya tulis-menulis atau dunia penerbitan buku-buku keagamaan Islam yang berbahasa Indonesia belum semaju seperti sekarang, baik itu buku terjemahan maupun ditulis oleh penulispenulis Indonesia. Bahkan para santri di pesantren jika belajar menterjemahkan dari kyainya langsung, tidak menulis dalam bahasa Indonesia atau bahasa daerah dengan huruf-huruf tersebut, melainkan memakai huruf Arab-Melayu atau orang Malaysia bilang Arab-Jawi. Barangkali dari kegiatan inilah kemudian lahir di Indonesia khususnya di dunia santri yang dinamakan hasyiyah, yaitu tulisan bergaya catatan pinggir, yaitu kitab ditulisi pinggirnya dengan berupa Syarah-nya dariisi kitab tersebut, yang didapat dari penjelasan seorang guru.

Demikian juga penyampaian hadis dari guru ke murid (Tahamul wa al-ada), umumnya menggunakan metode-metode tradisional. Misalnya, jika seorang murid ingin resmi dianggap muhadis, maka terlebih dahulu harus ada acara resmi pengijazahan hadis tersebut dari guru kepada murid-nya, atas suatu kitab hadis yang akan diajarkan kepada murid-muridnya pula. Padahal kegiatan penyampaian dan penerimaan riwayat (hadis) dari seorang guru kepada murid itu hanya berlaku ketika dilakukan penelitian terhadap para perawi hadis itu yang hendak menunjukkan ada dan tidaknya hubungan status guru-murid di antara perawi penyampai dengan perawi penerima itu oleh para ulama muhaddisin atau mukharij, seperti pada masa ulama penulis kutub al-sitlah.Para ulama muhaddisin menganggap teori ini sebagai suatu hal yang penting dipakai untuk melihat ketersambungan sanad hadis tersebut. Sebab dari situ akan diketahui mana sanad yang bersambung dan mana yang tidak bersainbung. Demikian pula dari situ diketahui pula mana para perawi yang mempunyai hubungan guru-murid, dalam artian proses penerimaan secara liqa (bertemu langsung) dan hanya $m u$ 'asarah (sezaman) saja. Sehingga dari proses penelitian dari sisi tahamul wa al-ada' ini diketahui kualitas sanad hadis itu sendiri, apakah tingkat ke-muttasil-annya pada tingkat liqa atau mu'asarah saja, yang tentu saja sanad hadis yang didalamnya terdapat perawi penyampai dan perawi penerima (guru-murid) yang berkualitas liqa itu lebih tinggi derajatnya daripada hanya tingkat mu 'asarah saja.

Oleh karena itu menurut hemat penulis, sistem pengijazahan ini dalam proses penyampaian hadis itu sudah tidak berlaku lagi. Karena seluruh hadis Nabi sudah dibukukan dan ditakhrij oleh para ulamanya sebelum mereka membukukan hadis-hadis yang mereka terima dari para perawi yang terdekat dengan mereka.

Namun itu tadi, barangkali untuk menghormati jerih-payah para ulama dalam menggeluti hadits, maka tradisi pengijazahan ini masih terus diberlakukan di Indonesia setidak-tidaknya pada kurun awal abad XX, Ini yang disebut penulis sebagai proses 
penyampaian hadis yang masih menggunakan metode-metode tradisional di atas.

Adapun para ulama hadis Indonesia pada paruh pertama abad XX, menurut catatan Daud Rasyid Harun, seorang doktor alumni Timur Tengah, ${ }^{12}$ bahwa para ulama hadis Indonesia pada masa kurun awal itu banyak sekali, tercatat sebanyak 69 orang. Namun Daud Rasyid tidak menjelaskan secara langsung batasan apa yang dipakainya sehingga seorang ulama itu termasuk ahli hadis. ${ }^{13}$ Barangkali Daud Rasyid memakai batasan yang paling umum tentang kriteria ulama tempo dulu, yang biasanya keluasan ilmunya sangat mumpuni, yang hampir saja menguasai berbagai cabang keilmuan Islam yang sangat banyak itu.Misalnya seorang ulama Indonesia tempo dulu itu bukan saja ahli tafsir dan fiqh, tetapi dia juga sangat menguasai hadis, walaupun tidak menyebarkan pengetahuannya itu melalui buku-buku yang ditulisnya, sehingga tercatatlah para ulama ahli hadis di Indonesia sebanyak itu. Dan ulama yang disebutkan sebagai ahli hadis Indonesia pada paruh pertama abad XX itu yang terkenal di antaranya adalah: 1). Ahmad Khatib bin Abdul Latif Minang kabau (1859-1918), 2) Muhammad Mahfudz bin Abdullah alTirmisi (1878-1919), 3) Hasyim Asy'ari Jombang (1865-1946), 4) A. Hassan (18861957), 5) Munawar Khalil (1908-1960), 6) TM, Hasbi Ash-Shiddieqy (1904-1974), 7)

12 Daud Rasyid Harun, Juhud Ulama Indonisiya Fi Al-Sunnah, Risalah Muqodimah Linail Darajat AlDaktarah Fi Al-Syari at Al-Islamiyya (kairo: Jami'ah al-Qahirah, 1996), p. 15.

13 Azyumardi Azra misalnya, ketika menguraikan biografi Abdussamad bin Abdurrahman al-palimbani, yang dalam daftar ulama ahli hadis versi Daud Rasyid tokoh ini di tempatkan pada nomor urut 7, tidak menyebutkan palimbani ini secara jelas sebagai ahli hadis. Demikian juga azyumardi ketika menguraikan Muhammah Arsyad al-Banjari, yang dsal;am daftar Daud Rasyid tokoh ini ditempatkan pada nomor urut8, tidak secara jelas menyebutkan al-Banjari sebagai ahli hadis. Azyumardi Azra, Jaringan Ulama Timur Tengah Dalam Keplauan Nusantara Abad XVII Dan XVIII, Melacak Akar-Akar Pembaruan Dan Pemikiran Islam Di Indonesia (Bandung: Mizan, 1995), pp. 24357.
Abdul Qadir Hassan Bangil (w. 1984), 8) Muhammad Yasin bin Isa Padang al-Makky (1916-1990).

Muhadis perlama, seperti tertulis di atas adalah Ahmad Khatib, kelahiran Bukit Tinggi, adalah salah seorang ulama pembawa paham pembaruan pemikiran Islam di Indonesia, atau yang lebih dikenal sebagai wahabisme itu. Ahmad Khatib pertama kali pergi belajar ke Mekkah pada tahun 1871, dan belajar kepada Sayyid Umar Syatha, Sayyid Utsman Syatha dan Abi Bakr Syatha. Sepulang dari Mekkah kemudian ia menyebarkan paham pembaruannya melalui Iembaga-Iembaga keagamaan di Minangkabau.

Pemikiran keagamaannya yang reformis tersebut tersebar dalam berbagai macam buku yang ditulisnya, baik dalam bahasa Melayu maupun bahasa Arab, yang menurut catatan Daud Rasyid Azyumardi Azra miszilnya, kclika ineiigumikan biografi Abdussamad bin Ahdurrahman alPalimbangi, yang dalam daftar ulama mencapai 46 buah buku. ${ }^{14}$ Namun tidak ada satu pun buku khusus tentang hadis yang ditulis oleh tokoh ini.

Muhadis kedua, adalah Mahammad Mahfudz bin Abdullah al-Tirmisi, yang lebih dikenal dengan nama Mahfudz al-Tirmisi. Kata al-Tirmisi itu adalah kampung kelahirannya di JawaTengah yang bernama Termas. Ia terkenal di Hijaj sebagai salah seorang tokoh muhadis dari Indonesia, yang pertama kali dikirim untuk belajar ke Mekkah oleh orang tuanya yakni Syeikh Abdullah al-Tirmisi yang dikenal didaerahnya sebagai ulama fuqaha, pada tahun $1291 \mathrm{H} / 1875 \mathrm{M}$. dan pergi untuk kedua-kalinya pada tahun 1314 yang selanjutnya bermukim dan wafat di Mekkah pada tahun 1919. Selama di Mekkah ia banyak belajar ilmu keagamaan Islam dari ulama-ulama di kota suci ini, termasuk hadis dan ilmu mushthalah hadis dari para ulama muhadisin yang terkenal di Timur Tengah.

\footnotetext{
14 Harun, p. 49.
} 
Selanjutnya ia kemudian mengajar dan menulis berbagai macam buku yang sangat banyak di kota ini hingga sampai wafatnya. Khusus buku hadis dan ilmu hadis, Muhammad Mahfudz al-Tirmisi menulis antara lain: 1) Manhaj dzaw-i al-nazhar fi syarh manzhumah ilmu al-atsar, 2) al-

Manhat al-khairiyah $f i$ arbain hadisan min ahadis khair al-bariyah, 3) al-Khal 'at alfikriyah

bisyarh al-munhat al-khairiyah, dan 4) Kifayah al-mustafid lima 'ala man alasaanid.

Kitab-kitab di atas merupakan kitab literatur ilmu hadis yang sangat penting dalam penelitian hadis. -Kitab yang pertama di atas misalnya, merupakan karya al-Tirmisi yang sampai sekarang masih terbit dan banyak beredar di Indonesia, karena kajian yang terdapat dalam kitab ini merupakan litelatur penting. Sebagai contoh, al-Tirmisi misalnya menyatakan bahwa periwayatan secara 'an 'anah yang tidak jelas itu, bila diriwayatkan oleh perawi yang Tsiqat, maka periwayatan itu bias diterima.Karena diduga kuat bahwa ketika seorang perawi itu hidup sezaman, segenerasi dengan seorang perawi yang ada di atasnya (guru), maka sangat dimungkinkan pada masa itu bisa benemu dan berkumpul antara keduanya. ${ }^{15}$

Muhadis ketiga, adalah Syekh Hasyim Asy'ari Jombang (I865-1946).Ia adalah pendiri Nahdhatul Ulama (NU) dan pendiri pesantren Jombang yang terkenal itu. Ia banyak mendidik para santrinya yang kemudian terkenal sebagai ulama besar Indonesia. Namun penulis kesulitan untuk mendapat referensinya yang lengkap tentang tokoh ini, termasuk buah karyanya di bidang hadis Hanya saja untuk membuktikan eksistensi tokoh ini, barangkali sudah cukup jelas tentang keberadaan pesantren Jombang di Jawa Timur yang terkenal itu, sehingga mampu melahirkan ulama tingkat nasional Bahkan cucunya, KH. Abdurrahman Wahid memimpin NU dewasa ini.
Muhadis keempat, adalah A. Hassan (1886-I957), tokoh ini terkenal sebagai Hassan Bandung yang sangat terkenal sebagai ahli perdebatan keagamaan Islam di Indonesia selama hidupnya.la merupakan guru besar Persatuan Islam (Persis), yang banyak melahirkan tokoh-tokoh Persis dalam kurun waktu kemudian, di samping tokohtokoh nasional seperti M. Natsir, dan HM. Isa An-shari. Bahkan Soekarno ketika di buang ke Endeh banyak melakukan korespondensi keagamaan dengan tokoh ini.

Pemikiran keagamaannya banyak tersebar dalam 157 buah buku, yang masih beredar hingga sekarang sekitar 50 buah buku saja di antaranya tafsir al-Furqan-nya yang ditulis sejak tahun 1930an. Pandangannya tentang hadis yang terpentingadalah antara lain: Hadis, dari segi boleh dipakai dan tidaknya sebagai dasar syari'at Islam, dibagi tiga macam: 1) Hadis Maqbul, yang boleh diterima, atau dipakai, 2) Hadits Dha'if, lemah, dan 3) Hadis Mawdhu (palsu). Sedangkan Hadis Maqbul ada tiga macam: 1) Hasan, 2) Shahih dan 3) Ashhah, lebih shahih. Dalam Hadis Ashhah ini termasuk Hadis Mutawarir, yakni Hadis yang didengar langsung dari Nabi oleh orang banyak, sehingga betul-betul yakni bahwa Hadis itu dari Nabi. Hadis Hasan boleh dijadikan alasan kalua tidak berlawanan dengan alQur'an, dengan Hadis Shahih atau dengan Hadis Ashhah.Hadis Shahih boleh dibuat dalil apabila tidak berlawanan dengan alQur'an atau dengan Hadis Ashhah.Hadis Ashhah boleh dijadikan dalil jika tidak berlawanan dengan al-Qur'an.

Demikian, A. Hassan menempatkan kedudukan al-Qur'an pada posisi utama dan pertama, sehingga ia bisa mendrop Hadis sekalipun shahih menurut sanad-nya tetapi dianggap berlawanan dari segi matan-nya, seperti dalam masalah Hadis yang membolehkan "haji wakil". Ia menolaknya,

${ }^{15}$ Muhammad Mahfudz Al-Tirmisi, Manhaj Dzaw Al-Nazhar (Beirut: Darr al-Fikr, 1981), p. 56. 
karena menurut pendapatnya berlawanan dengan al-Qur'an. ${ }^{16}$

Muhadis kelima, adalah Munawar Khalil (I908-1960), seorang ulama dari Semarang, Jawa Tengah, ia juga mempakan tokoh ulama Persatuan Islam, yang bersama-sama A. Hassan dan TM. Hasbi Ash-Shiddieqy duduk di Majlis Ulama Persatuan Islam. Pandangan keagamaannya yang tercermin termasuk pandangannya terhadap hadis adalah terdapat dalam bubu-buku yang telah ditulisnya, antara lain yang masih beredar adalah buku: Kembali kepada Alquran dan alSunnah,terbitan Bulan Bintang, Jakarta.

Muhadis keenam dan ke lujuh yaitu: T.M. Hasbi Ash-Shiddieqy (1904-1974),dan Abdul Qadir Hassan Bangil (putra A. Hassan yang wafat I984), yang juga tokoh ulama Persatuan Islam sepeninggalan A. Hassan, pandangan keagamaannya terutama hadis, akan ditemukan di bagian selanjutnya makalah ini, yaitu ketika mengungkap data buku-buku ilmu hadits di Indonesia.Muhadis kedelapan, yaitu Muhammad Yasin bin Isa al-Padani al-Makky (1916-1990), adalah muhadis Indonesia yang berasal dari Padang dan bermukim di tanah suci Mekkah hingga wafatnya. Meskipun ia tinggal di Mekkah, namun nasionalisme Indonesianya tidak pernah luntur, ia banyak memperhatikan perkembangan keagamaan Islam di Indonesia, terbukti telah beberapa kali pulang ke Indonesia dan murid-muridnya banyak tersebar di tanah airPemikiran keagamaannya terutama tentang hadis, ia barangkali satusatunya ulama yang masih mempenahankan ciri penyampaian hadis dengan memakai metode ijazah, dalam artian bahwa seseorang itu jika ingin menyampaikan hadis kepada murid-muridnya melalui kitab-kitab hadis yang mu'tabar itu harus berijazah dari gurunya. Kebetulan ia sebagai muhadis yang mempunyai banyak murid di Indonesia, maka dalam suatu kesempatan berkunjung ke Indonesia, ia sempat memberi (jazah dalam

16 A. Hassan, Risalah Al-Qur'an Dan Al-Sunnah (Bangil: Penerbitan Pesantren Persatuan Islam, 1972), p. 22. suatu upacara khusus kepada murid-muridnya, dengan cara terlebih dahulu seorang murid membaca hadis dalam sebuah kitab hadis di hadapan beliau, kemudian ia menyatakan: ajaztuka, maka resmilah murid itu sebagai muhadis.

Pemikiran keagamaan tokoh yang satu ini, khususnya tentang hadis terlebih metode ijazah tersebut dalam penyampaian hadis, adalah tercatat dalam kitab ilmu hadis karyanya: Sad al-arab min 'ulum al-isnadi wa al-adab, terbitan Mathba'ah Hijaziy, Mekkah. Karena menurut dia, metode ijazah itu mempakan tradisi para ulama salaf dalam kegiatan ilmiah. ${ }^{17}$

\section{Periode Penerjemahan Hadis dan Pengembangan Ilmu Hadis pada Kurun Akhir}

Sebelum merdeka penyebaran hadis di Indonesia berbentuk kitab-kitab hadis dalam teks bahasa Arab Kitab-kitab ini umumnya terbitan Kairo-Mesir dan Beirut-Libanon yang banyak dimiliki oleh para ulama Indonesia.Namun dalam jumlah yang sangat terbatas.Oleh sebab itu penyebaran hadis di kalangan umat Islam Indonesia masih sangat minim.Hal yang menjadi kendala utamanya barangkali terletak pada pemahaman bahasa Arabnya yang sangat minim pula.

Sementara penyebaran hadis di Indonesia yang berbentuk terjemahan hanya sebagian kecil saja, kalau tidak boleh dikatakan tidak ada bentuk penerjemahan sama sekali, dan terbatas untuk hadis-hadis yang berbentuk himpunan. Itu pun bersifat himpunan hadishadis fiqh, karena langkanya usaha penerbitan hadis dalam negeri, dan menggantungkan sepenuhnya penerbitan di luar negeri yang telah dijelaskan di muka. Bahkan menurut hasil penelitian yang dilakukan oleh I. Nurol Aen, ${ }^{18}$ tentangkap

17 Untuk lebih jelasnya, lihat Muhammad Yasin Ibn Isa al-Padani al-Maky, "al-Raud al-Nadhir $f i$ ' al-ittisalani wa majmu ijazani bitsabt al-amir", hlm. 18, dalam buku Sad al-arab min 'ulum al-isnadi wa $a l$-adab di atas.

${ }^{18}$ Nurol Aen, 'Perkembangan Literarur Hadis Di Indonesia', Majalah Istiqra No. 6/th.VI/Juli-Desembe, 
bahwa di berbagai pesantren, kitab-kitab hadis terbitan luar negeri itu dijadikan bahan pelajaran di antaranya di surau Jembatan Besi (Minangkabau), sejak tahun $1916 \mathrm{M}$. Kitab hadis al-Arbain harus dihafal oleh para siswa. Bila tidak, maka dihukum berjamjam. ${ }^{19}$ Sejak tahun $1918 \mathrm{M}$ kitab hadis dan mushthalah hadis merupakan pelajaran siswa kelas I sampai kelas 5 di Madrasah Muhammadiyah Yogyakarta. Pada tahun I920-an kitab Jawahir al-Bukhari telah diajarkan di Parabek dan Padang Panjang. ${ }^{20}$ Di Pesantren Modern Gontor Ponorogo, sejak tahun 1926 kitab Bulugh al-Maram telah diajarkan kepada para santrinya dengan memakai bahasa Arab sebagai pengantarnya. ${ }^{21}$ Kitab ini dipakai pula sebagai bahan utama pelajaran hadis di Pesantren Persatuan Islam (PERSIS) Bandung pada tahun $1930 .{ }^{22}$ Bahkan meski ada perubahan kurikulum dewasa ini, pesamren ini tetap memakai kitab Bulugh al-Maram, di samping kitab Shahih al-Bukhari sebagai bahan pelajaran hadis.

Selanjutnya masa penerjemahan hadis pun tiba saatnya, yang tentunya didukung oleh lembaga penerbitan yang siap memenuhi pasar pembaca muslim, yang rentetannya sebagai berikut:

Pada tahun 1937, kitab Shahih al-Bukhari telah diterjemahkan oleh $\mathrm{H}$. Zainuddin IIamidy,Fachruddin Hs., Nasaruddin Thaha dan Djohar Arifin. Terjemahan ini kemudian diterbitkan Wijaya , Jakarta dalam bentuk buku pada tahun 1957, 1961, 1966, 1970, 1921, dan $1923 .^{23}$

December 1992. Data dalain tulisan ini sebagian merujuk pada data temuan dalam tulisan ini.

19 Noer, Gerakan Modern Islam Di Indonesia 1900-1942, p. 54.

${ }^{20}$ Mahmud Yunus, Sejarah Pendidikan Islam Di Indonesia (Jakarta: Mutiara, 1979), p. 77.

${ }^{21}$ Keterangan ini diperoleh Bapak I. Nurol Aen pada tahun I971 dari ustadz Syirman, salah seorang guru hadis di pondok Gontor Ponorogo ketika ia menjadi santri di pesantren ini.

${ }^{22}$ Yunus, p. 77.

${ }^{23}$ Zainuddin Hamidy, Terjemahan Shahih Bukhari (Jakarta: Wijaya, 1983).
Adapun brosur dan majalah yang banyak memuat hadis, yang tentunya disertai terjemahannya terdapatkan antara lain pada:

1. Himpunan Putusan Tarjih tahun 1929 s-d 1972; dalam himpunan ini termuat 534 hadis. Sembilan hadis dalam masalah aqidah, 517 hadis dalam masalah ibadah dan delapan hadis dalam masalah akhlak. $^{24}$

2. Majalah Soal Jawab tahun 1931 a-d 1934; diterbitkan oleh A. Hassan dan pemimpinpemimpin persatuan Islam. Di dalamnya terdapat jawaban-jawaban terhadap penanyaan mengenai masalah-masalah agama. Pada tahun 1968 majalah Soal Jawab ini diterbitkan oleh CV Diponegoro dalam bentuk buku terdiri dari tiga jilid. Dalam buku ini termuat I429 buah hadis. 124 buah hadis mengenai aqidah, 1279 buah hadis mengenai fiqh dan 26 buah hadis mengenai akhlak. ${ }^{25}$

Dari uraian di atas dapat disimpulkan bahwa hadis-hadis yang dimuat dalam brosur dan majalah berjumlah 1971. 136 buah hadis mengenai aqidah, 1798 buah mengenai fiqh dan 37 buah hadis mengenai akhlak.

Dari data di atas jelas bahwa bahasan fiqh lebih banyak bila dibandingkan dengan bahasan aqidah dan akhlak.Hal ini disebabkan orientasi pemikiran sebagian besar ahli-ahli agama pada waktu itu tertumpu kepada masalah ibadah praktis sehari-hari. Bahkan bagi golongan tradisional, Islam seakan-akan sama dengan fiqh. $^{26}$

Sesudah kemerdekaan, perkembangan hadis di Indonesia mengalami kemajuan.Berbagai jenis koleksi telah diterbitkan dalam bentuk yang lebih sempurna, ada yang berbentuk terjemahan danada pula yang berisikan kumpulan atau himpunan hadis.

Dalam bentuk terjemahan, dapat diketahui buku-buku sebagai berikut:

24 PP Muhammadiyyah, Himpunan Putusan Takhrij 1929-1972 (Yogyakarta).

25 A. Hassan, Soal Jawab Jilid I-III (Bandung: CV. Diponegoro, 1983).

${ }^{26}$ Noer, Gerakan Modern Islam Di Indonesia 1900-1942, p. 320. 
1. Al-.Jami'al-Shahih susunan Imam alBukhari, diterjemahkan oleh $\mathrm{H}$. Zaenuddin Hamidy dkk. dalam empat jilid, kemudian diterbitkan oleh penerbit Wijaya Jakarta pada tahun1957, 1961,1966, 1970, 1981, dan 1983. Memuat 1125 buah hadis; 55 buah hadis mengenai aqidah, 1012 buah hadis mengenai fiqh dan 58 hadis mengenai akhlak. Materi hadis-hadis itu kemudian diterjemahkan menurut susunan teks aslinya. Materi hadis yang terdapat dalam kitab aslinya tidak diteijemahkan seluruhnya. Oleh sebab itu, keempat jilid buku terjemahan ini hanya merupakan koleksi. Hal ini bisa dilihat dengan diterjemahkannya satu buah hadis dari beberapa materi hadis yang mempunyai arti sama dalam matn dan sanadnya. Begitu pula ayat-ayat al-Qur'an, perkataan sahabat-sahabat Nabi serta beberapa sanad yang terclapat dalam teks asli tidak diterjemahkan. Keterangan atau pendapat lain dari penerjemah tidak didapatkan dari keempat buku tersebut. Hanya saja kadang-kadang didapatkan catatan kaki untuk menerangkan arti kata yang sulit. ${ }^{27}$

2. Al-Jamî al-Shahih susunan Imam Muslim; diterjemahkan oleh H.A. Razaq dkk. dalam empat jilid dan diterbitkan oleh penerbit Pustaka al-Husna Jakarta. Susunan materi Hadis diterjemahkan menurut susunan teks aslinya. Dalam keempat jilid itu termuat 1503 buah hadis, 233 buah hadis mengenai aqidah, 968 buah hadis mengenai fiqh dan 302 buah hadis mengenai akhlak. Metode penyusunan materi dan metode penerjemahan dan penulisan dalam keempat jilid terjemahan bukutersebut sama dengan yang dilakukan oleh $\mathrm{H}$. Zainuddin dkk. dalam menerjemahkan kitab al-Jami' al-Shahih susunan Imam Bukhari tersebut di atas. Keterangan atau pendapat lainnya dari penerjemah keempat jilid ini pun tidak didapatkan. ${ }^{28}$

\footnotetext{
${ }^{27}$ Hamidy.

${ }^{28}$ A Razaq, Terjemahan Shahih Muslim (Jakarta: Pustaka al-Husna, 1978).
}

3. Bulugh al-Maram susunan Ibn Hajar al'Asqalani; kitab ini diterjemahkan oleh A. Hassan dalam duajilid dan diterbitkan oleh CV Diponegoro tahun 1967, 1969, 1970, 1972, 1974, 1976, 1979,1981, dan 1983. Seluruh materi hadis diterjemahkan dan susunannya disesuaikan dengan susunan teks aslinya. Kitab terjemahan ini memuat 1596 buah hadis, 1470 hadis mengenai fiqh dan 126 buah hadis mengenai akhlak. A. Hassan selain menterjemah juga menguraikan berbagai pendapat ulama tentang hadis yang diterjemahkannya, serta memberikan dan menguraikan pendapat pribadinya. Inilah kelebihan penerjemah A. Hassan bila dibandingkan dengan penerjemah lainnya. ${ }^{29}$

4. Riyadh al-Shalihin, susunan Imam Abu Zakaria Ibn Syaraf al-Nawawi; kitab ini diterjemahkan oleh H. Salim Bahreisy dalam dua jilid dan diterbitkan oleh PT. Al-Ma'arif Bandung pada tahun 1983. Seluruh materi hadis ini diterjemahkan dan susunannya disesuaikan dengan teks aslinya. Kitab terjemahan ini memuat 1822 buah hadis; 66 buah hadis mengenai fiqh clan 1756 buah hadis mengenai akhlak. Hampir di akhir setiap hadis yang diterjemahkan, penerjemah memberikan penjelasan mengenai maksud hadis yang diterjemahkannya itu. ${ }^{30}$

5. Al-Ahadis al-Qudsiyah susunan al-Majlis al-A'la li Syu'un al-Islamiyah Kairo. Kitab ini diterjemahkan oleh M. Zuhri ke dalam satu jilid dan diterbitkan oleh CV Toha Putra Semarang tahun 1981. Seluruh materi hadis diterjemahkan dan susunannya disesuaikan dengan teks aslinya. Kitab terjemahan ini memuat 409 buah hadis; 162 buah hadis mengenai aqidah, 11 buah hadis mengenai fiqh dan 136 buah hadis mengenai akhlak. Kadangkadang di akhir setiap hadis yang diterjemahkan, penerjemah memberikan

\footnotetext{
${ }^{29}$ A. Hasan, Terjemahan Bulugh Al-Maram (Bandung: CV. Diponegoro, 1983).

${ }^{30}$ Salim Bahreisy, Terjemhan Riyadh Al-Shalihin (Bandung: al-Ma'arif, 1983).
} 
ulasan seperlunya yang dianggap penting. ${ }^{31}$

6. Al-Lu'lu wa al-Marjan susunan Muhammad Fuad Abd al-Baqi; kitab ini diterjemahkan oleh H.Salim Bahreisy dalam dua jilid dan diterbitkan oleh PT. Bina Ilmu Surabaya pada tahun 1981. Seluruh materi hadis diterjemahkan dan susunannya disesuaikan dengan susunan teks aslinya. Kitab terjemahan ini memuat 1906 buah hadis; 167 buah hadis mengenai aqidah, 1541 buah hadis mengenai fiqli dan 198 buah hadis mengenai akhlak. Keterangan atau penjelasan lain dari penerjemah tidak didapatkan di dalam buku terjemahan ini. $^{32}$

Dari uraian tersebut di atas terlihat bahwa penerjemah lebih cenderung tidak memberikan catatan atau komentar serta pendapat pribadinya dari hadis-hadis yang diterjemahkannya kecuali A.Hassan.

Dalam bentuk himpunan, dapat diketahui buku-buku sebagai berikut:

a. 2002 Mutiara Hadis; terdiri dari tujiuh jilid. disusun oleh T.M. Hasbi AshShiddieqy dan diterbitkan oleh Bulan Bintang pada tahun 1954, 1955, 1961, dan 1975. Buku himpunan ini memuat 2002 buah hadis; 171 hadis mengenai aqidah, 1649 hadis mengenai fiqh dan 182 hadis mengenai akhlak. 2002 Mutiara Hadis ini dihimpun dari dua sumber kitab; kitab Zad al-Muslim susunan al-Syanqiethy dan kitab al-Lu 'lu wa al-Marjan susunan Muhammad Fuad Abd al-Baqi. ${ }^{33}$

b. Koleksi Hadis-Hadis Hukum, terdiri dari sebelas jilid, disusun oleh T.M. Hasbi Ash-Shiddieqy dan diterbitkan oleh PT. A]-Ma'arif Bandung pada tahun 1966 dan 1972. Memuat 1606 buah hadis hukum (fiqh) yang dihimpun dari berbagai kitab; kitab Muntaqa al-Akhbar susunan Majdu al-Din al-Harrany, kitab Bulugh alAlaram susunan Ibn Hajar al-'Asqalany.

\footnotetext{
${ }^{31}$ M. Zuhri, Terjemahan Al-Hadits Al-Qudsiyah (Semarang: CV. Toha Putra, 1981).

${ }^{32}$ Salim Bahreisy, Terjemahan Al-Lu'lu Wa Marjan (surabaya: PT Bina Ilmu, 1981).

${ }^{33}$ M. Hasbi Ash-Shiddieqy, 2002 Mutiara Hadits (Jakarta: Bulan Bintang, 1954), p. 16.
}

dan kitab Umda al-Ahkam susunan Abd al-Ghani al-Maqdisy. Untuk memahami hadis yang diterjemahkan, penyusun memberikan keterangan-keterangan sebagai bahan pegangan bagi para pembacanya. Sistematika himpunan hadis yang disusun oleh T.M. Hasbi AshShiddieqy jauh lebih baik dan sempurna bila dibandingkan dengan sistematika penulis himpunan yang lainnya. Hal ini karena ai samping kedua buku itu memakai bahasa yang mudah dipahami, juga berbagai pendapat para mujtahid dijelaskan secara terperinci dan penyaringan serta pentahkikannya pun diuraikan secara teliti. Dengan demikian patutlah bila T.M. Hasbi Ash-Shiddieqy dikatakan sebagai pembaharu dan pemikir dalam penulisan hadis di Indonesia, meskipun umumnya terbatas pada bahasan hadis-hadis mengenai fiqh.

c. Hadis-hadis tentang Peradilan Agama; disusun oleh Fatchurrahman dan diterbitkan oleh Bulan Bintang Jakarta pada tahun 1977. Buku ini memuat 94 buah hadis mengenai fiqh yang berkisar pada masalah hakim, gugatan, pembuktian, saksi, sumpah, dan hal-hal lain yang berhubungan dengan peradilan. Seluruh materi hadis yang berteks Arab diterjemahkan dan kemudian diberikan berbagai keterangan dan uraian secara jelas dan terperinci, sehingga memudahkan bagi para pembaca untuk memahaminya. ${ }^{34}$

d. Mutiara Qur'an dan Hadis; disusun oleh H. Abd al-Aziz Masyhuri, dan kemudian diterbitkan oleh al-Ikhlas Surabaya pada tahun 1982. Buku ini mengandung dua mata pelajaran, pelajaran al-Qur' an dan al-Hadis. Materi kedua pelajaran disesuaikan dengan kurikulum 1980 (Keputusan Menteri Agama RI No.24 th. 1980), serta diperuntukkan bagi para pelajar Madrasah Tsanawiyali dan Madrasah Aliyah jurusan IPS, Bahasa, Syari'ah dan Qadha. Dalam buku ini khusus mengenai materi hadis termuat

\footnotetext{
${ }^{34}$ Fathurrahman, Hadits-Hadits Tentang Peradilan Agama (Jakarta: Bulan Bintang, 1977)..
} 
253 buah hadis, 59 buah hadis mengenai aqidah, 87 buah hadis mengenai akhlak dan 107 buah hadis mengenai fiqh. Seluruh materi hadis diterjemahkan dan susunannya disesuaikan dengan kurikulum 1980 tersebut. Keterangan atau penjelasan lain dari penyusun buku ini tidak didapatkan sedikit pun. ${ }^{35}$

e. Himpunan Hadis Shahih Bukhari; disusun oleh Hussein Bahreisy dan diterbitkan oleh Al-lkhlas Surabaya pada tahun 1981. Isi buku ini khusus memuat hadis-hadis yang diriwayatkan Imam al-Bukhari, yang susunannya disesuaikan dengan pilihan penyusun. Buku himpunan ini memuat 625 buah hadis; 57 buah hadis mengenai aqidah, 26 buah hadis mengenai akhlak dan 542 buah hadis mengenai figh. Mengenai keterangan atau penjelasan lain dari penghimpunan hadis ini tidak didapatkan. ${ }^{36}$

f. Jawahir al-Ahadis; disusun dalam bahasa Arab oleh Mawardi Muhammad, dan diterbitkan oleh Pustaka Sa'diyah Padang Panjang pada tahun 1950-an. Buku ini banyak dipakai sebagai buku pegangan pelajar-pelajar di berbagai madrasah di Sumatra Barat. Memuat 167 hadis yang secara keseluruhannya berkaitan dengan akhlak. Keterangan atau penjelasan lain dari penyusunan buku ini tidak didapatkan. ${ }^{37}$

g. Kumpulan Hadis Dha'if dan Palsu; disusun oleh Ustadz A. Yazid Qasim Koho dan diterbitkan oleh Bina Ilmu Surabaya, tanpa tahun terbit. Dalam buku ini termuat 161 buah hadis; 58 buah hadis mengenai aqidah, 22 buah hadis mengenai akhlak dan 181 buah hadis mengenai fiqh Keterangan atau penjelasan hadis dari pengumpul buku ini diuraikan dengan jelas dan terperinci. Buku ini merupakan buku pertama dalam koleksi hadis-hadis

\footnotetext{
${ }^{35}$ H. Abdul Aziz Masyhuri, Mutiara Qur'an dan Hadis, (Surabaya: al-Ikhlas, 1982).

${ }^{36}$ Salim Bahreisy, Himpunan Hadis Shahih Bukhari (surabaya: Al-Ikhlash, 1981).

${ }^{37}$ Mawardi Muhammad, Jawahir Al-Hadits (Padang Panjang: Pustaka Sa'diyah, 1950).
}

dha'if dan palsu yang diterbitkan di Indonesia. ${ }^{38}$

h. Mahkota Pokok-Pokok Hadis Rasulullah SAW., sebanyak lima jilid tebal, terjemahan dari kitab al-Taj al-Jami' li alUshulfi Ahadits al-Rasul, yang ditulis oleh Syeikh Mansyur Ali Nashef.

i. Shahih Bukhari dalam terjemahan bahasa daerah, yaitu bahasa Sunda. Buku ini diterjemahkan oleh K.H. HMD. Ramli dalam dua jilid tebal, dilengkapi dengan terjemahan biografi dan metodologi yang ditempuh oleh al-Bukhari dalam mengumpulkan hadis dan menulis kitab Shahih-nya. Buku ini pertama kali terbit pada tahun 1969 dan diterbitkan oleh penerbit Al-Ma'arif, Bandung.

j. Hadis-Hadis Pilihan, dalam satu jilid tebal berikut penjelasannya. Buku ini diterjemahkan oleh Moch. Anwar dkk. dan kitab hadis Mukhtar al-Ahadis, karya Sayyid Ahmad al-Hasyimi. Buku terjemahan ini diterbitkan oleh Sinar Baru, Bandung tahun 1983.

k. Sunan Abu Dawud diterjemahkan oleh H. Bey Arifin dan A. Syanqithy Djamaluddin dari kitab Mukhtashar Sunan Abu Dawud, susunan al-Munzhiri. Terjemahan dalam dua jilid tebal ini

diterbilkan oleh CV. Asyifa, Semarang, Februari 1992

1. Sunan al-Tirmidzi diterjemahkan oleh $\mathrm{H}$. Mob. Zuhri dkku dalam limajilid tebal, masing-masing jilid mencapai 700 halaman. Buku terjemahan ini diterbitkan oleh CV. Asy-Syifa, Semarang Oktober 1992.

m. Muwaththa Imam Malik, diterjemahkan oleh Adib Bisri Musthofa dkk. dalam dua jilid tebal dan dlterbitkan oleh CV. AsySyifa, Semarang, September 1992.

Sementara terjemahan kitab syarh hadis dalam bahasa Indonesia di antaranya adalah:

a. Subul al-.Salam syarh Bulugh al-Maram, diterjemahkan oleh Abu Bakar Muhammad dalam empat jilid tebal sesuai dengan kitab aslinya. Buku ini diterbitkan oleh penerbit al-Ikhlas, Surabaya tanpa

\footnotetext{
${ }^{38}$ A. Yazid Qasim Koho, Kumpulan Hadits Dha' if Dan Palsu (surabaya: PT Bina Ilmu).
} 
tahun terbit. Namun diperkirakan jilid pertama diterbitkan tahun 1986.

b. Nail al-Awthar, Himpunan Hadis-Hadis Hukum, diterjemahkan dalam enam Jilid tebal oleh A. Qadir Hassan, Mu'amal Hamidy, Imron AM dan Umar Fanany.

c. Syarh Hadis Arba'in, diterjemahkan oleh Zaini Dahlan dan diterbitkan untuk pertama kalinya oleh penerbit Trigenda Kaiya Bandung pada tahun 1995.

d. Al-Jami' al-Shaghir, diterjemahkan oleh H. Nadjih Ahjad dalamlima jilid tebal sesuai dengan aslinya. Buku ini diterbitkan secara lengkap oleh PT. Bina Ilmu Surabaya pada tahun 1996. Kecenderungan penghimpun dan penerjemah dalam memilih hadis-hadis kelihatan cukup bervariasi. Ditinjau dari segi koleksi hadis terdapat kecenderungan para penghimpun dan penerjemah untuk:

a. Menghimpun atau menerjemahkan hadishadis yang berkaitan dengan masalah hukum. Hal ini dapat dijumpai dalam koleksi hadis-hadis Hukum, hadis-hadis tentang Peradilan Agama, Bulugh alMaram, Al-Lu 'lu wa al-Marjan, dan Himpunan Hadis Shahih Bukhari.

b. Menerjemahkan atau mengimpun hadishadis yang berkaitan dengan akhlak. Hal ini dapat dijumpai dalam kitab Riyadh alShalihin dan himpunan kitab Jawahir alHadis.

c. Menghimpun atau menerjemahkan hadishadis yang berkaitan dengan berbagai bidang termasuk masalah aqidah, fiqh dan akhlak. Hal ini dapat dijumpai dalam 2002 Mutiara Hadis, buku terjemahan al-Jami' al-Shahih al-Bukhari dan al-Jami' alShahih Muslim.

Dari uraian di atas dapat diketahui pula bahwa hadis-hadis yang membahas persoalan-persoalan selain fiqh masih banyak yang belum dikaji dan dijamah oleh para ahli hadis Indonesia.Demikian pula usaha pengumpulan hadis yang khusus berkaitan dengan masalah aqidah belum mendapat perhatian yang maksimal. Juga hadis-hadis yang menerangkan dan memperkuat ayatayat al-Qur' an serta hadis-hadis mengenai kisah para Nabi belum terkodifikasikan dalam bentuk buku. Barangkali kekurangan ini menjadi tantangan tersendiri bagi para cendekiawan muslim Indonesia untuk melengkapinya di kemudian hari.

Dan sini kiranya dapat menggambarkan bahwa perkembangan hadis di Indonesia cukup variatif, dari mulai brosur dan majalah hingga berbentuk buku, baik berupa terjemahan maupun himpunan atas hadishadis, dari yang shahih hingga yang palsu.Bahkan dewasa ini perkembangan hadis di Indonesia telah memasuki era baru, yakni memasuki era teknologi.Hal ini terlihat dengan munculnya komputerisasi hadis shahih al-Bukhari bersamaan dengan komputerisasi al-Qur' an itu sendiri, baik melalui software maupun CDROM-nya. Namun dari segi kuantitatif, perkembangan hadis ini, jika dilihat dari dunia penerbitan, sebagian besar masih berkisar di sekitar hadis-hadis yang erat kaitannya dengan masalah fiqhiyah.

Sementara perkembangan ilmu hadis di Indonesia tampaknya cukup bersaing antara buku-buku terjemahan baik dari bahasa Arab maupun dari bahasa Inggris, dengan bukubuku yang ditulis oleh cendekiawancendekiawan muslim Indonesia. Hal ini bukan saja sangat membanggakan tapi juga memacu perkembangan penelitian hadis itu sendiri.Namun sayangnya penyebaran buku yang membahas ilmu hadis ini masih terbatas di sekitar kampus atau lembaga-lembaga pendidikan saja, belum menyebar luas di kalangan masyarakat sebagaimana kitabkitab hadis yang membahas matnhadis, seperti dikemukakan di atas.

Data-data buku yang membahas ilmu hadis tersebut yang layak dikemukakan antara lain adalah:

a. Sejarah dan Pengantar Ilmu Hadis, karangan T.M. Hasbi Ash-Shiddieqy. Buku ini pertama kali terbit tahun I954, dan diterbitkan oleh Bulan Bintang Jakarta. Hingga tahun 1993 telah mengalami cetak ulang ke XI. Buku ini barangkali termasuk buku ilmu hadis yang paling tua di Indonesia.

b. Status Hadis sebagai Dasar Tasyri', ditulis oleh Barmawie Umarie. Buku ini diterbitkan oleh AB Siti Syamsiyah, Sala, tahun 1965. 
c. Ilmu Mushthalah Hadis, ditulis oleh Fatchurrahman. Buku ini diterbitkan oleh PT Alma'arif, Bandung cetakan penama tahun 1968.

d. Al-Hadils sebzgai Sumber Hukum, terjemahan penerbit CV. Diponeggoro dan diterbitkan oleh: penerbit yang sama pada tahun 1979. Buku ini berasal dari buku alSunnah wa Makanatuha fi Tasyri ' alIslam, yang ditulis oleh Mushthafa alSyiba'i.

e. Ilmu Mushthalah Hadis, ditulis oleh A. Qadir Hassan diterbitkan oleh PT. Bina Ilmu, Surabaya, tahun 1979. Buku ini terus mengalami cetak ulang hingga kini.

f. Kaedah-kaedah Kesahihan Sanad Hadis, Ditinjau dari Ilmu Sejarah, ditulis oleh M. Syuhudi Ismail. Diterbitkan oleh penerbit Bulan Bintang, Jakarta tahun 1988. Buku ini berasal dari disertasi penulisnya ketika kuliah di Pasca Sarjana IAIN Syarif Hidayatullah, Jakarta.

g. Cara Praktis Mencari Hadis, ditulis oleh M. Syuhudi Ismail. Diterbitkan oleh penerbit Bulan Bintang, Jakarta tahun 1991.

h. Metodologi Penelitian Hadis Nabi, ditulis oleh M. Syuhudi Ismail yang berasal dari makalahnya untuk bahan seminar di Dirasah Ulya Pendidikan Tinggi Purnasarjana Agama Islam Medan, November 1991. Diterbitkan oleh penerbit Bulan Bintang, Jakarta tahun 1992.

i. Hadis Nabi yang Tekstual dan Konteksual, ditulis oleh M. Syuhudi Ismail. Diterbitkan oleh penerbit Bulan Bintang, Jakarta tahun 1994.

j. Kitab Hadis yang Enam, terjemahan Maulana Hasanuddin, dari kitab Fi Rihab al-Sunnah al-Kutub al-Shihah al-Sunnah, karya Muhammad Muhammad Abu Syuhbah, diterbitkan oleh PT. Pustaka Litera AntarNusa, Jakarta, cet. pertama tahun 1991.

k. Membahas Ilmu-Ilmu Hadis, terjemahan tim penerbit Pustaka Firdaus, Jakarta dan diterbitkan oleh penerbit yang sama pada tahun 1993.

1. Ilmu Hadis, ditulis oleh $H$. Endang Soetari, Ad. Diterbitkan oleh Penerbit
Amal Bhakti Press, Bandung tahun 1991 dan kini telah mengalami cetak ulang.

m. Problematika Hadis Mengkaji Paradigma Periwayatan, ditulis oleh $H$. Endang Soetari, Ad. Diterbitkan oleh Penerbit Gunung Djati Press, Bandung tahun 1994.

n. Ulum al-Hadits, terjemahan Mujio. Buku ini diterjemahkan dari Manhzy al-Naqdfi 'Ulum al-Hadits yang ditulis oleh Nuruddin 'Ithr. Diterbitkan oleh penerbit Remaja Rosdakarya, Bandung pada tahun 1994.

o. Pengembangan Pemikiran terhadap Hadis. Buku ini merupakan kumpulan makalah dari hasil seminar nasional yang diselenggarakan oleh Universitas Muhammadiyah Yogyakarta, 22-23 Pebruari 1992.

p. Metode Takhrij Hadis, diterjemahkan oleh HS. Agil Husin Munawwar, dkk, dari kitab Thuruq Takhrij' Hadits Rasul SAW, karya Abu Muhammad Abd al-Mahdi Ibn Abd al-Qadir Ibn Ab al-Hadis, diterbitkan oleh Penerbit Dina Utama, Semarang, cet. pertama 1994,

q. Pokok-pokok Ilmu Hadis, diterjemahkan oleh HM. Qodirun Nur, dkk. Dari kitab Ushul al-Hadits karya M. Ajaj al-Khathib. Diterbitkan oleh Gaya Media Pratama Jakarta, cet. pertama 1998.

Di antara sekian banyak buku yang membahas ilmu hadis, yang tersebar di Indonesia, terdapat beberapa buah yang membahas dan menyoroti pandangan orientalis terhadap hadis Nabi, di antaranya:

a. Hadis dalam Persoalan, ditulis oleh M. Thalib dan diterbitkan oleh PT. Almafarif, Bandung pada tahun 1978. Buku ini berisikan analisis terhadap pandangan kaum Orientalis yang banyak dikemukakan dalam buku Fajr al-Islam, yang ditulis oleh Ahmad Amin.

b. Hadis Nabawi dan Sejarah Kodifikasinya, terjemahan H. Ali Mushthafa Ya'qub dan diterbitkan oleh Pustaka Firdaus, Jakarta, tahun 1994. Buku ini berasal dari disertasi M.M. Azmi yang berjudul Studies in Early Hadith Literature. Buku teijemahan ini sangat tebal bila dibandingkan dengan rata-rata buku terjemahan yang ada saat ini di Indonesia. 
Al-Qur'an dan al-Hadits dalam sorotan Orientalis, ditulis oleh H. Salimuddin A. Rahman, diterbitkan oleh penerbit Karya Kita Bandung, pada tahun 1987. Buku ini berisikan kritik yang sangat tajam dan argumentatif terhadap pandangan kaum orientalis yang meragukan terhadap alQur'an dan al-Hadis. Namun sayangnya buku ini tidak orisinal. Bahkan jika boleh dijelaskan lebih lanjut, tampak penulisnya telah memindahkan dari buku lain. Hampir selurulmya buku di atas berasal dari buku yang ditulis oleh Hammad Hasan Lubis, terbitan Dewan Da'wah Islamiyah Indonesia (DDII), Jakarta pada tahun I972.

\section{SIMPULAN}

Demikian selintas tentang perkembangan hadis di Indonesia pada abad XX, di mana pada kurun itu terdapat dua gelombang besar yang menyertai perkembangan hadis, yaitu kurun penyebaran yang masih mempola abad sebelumnya yaitu bercorak tradisional. Sementara kurun selanjutnya, ada perubahan yang mendasar dari pola pengajaran dalam mata ajar hadis, yang semula berbahasa Arab, namun secara diam-diam diubah menjadi bahasa Indonesia terutama dari segi referensinya. Hal ini terutama semenjak kemunculan madrasah Aliyah di nusantara.Dari sini kemudian muncul sebagai konsekuensi logisnya yaitu gelombang penerjemahan kitab-kitab hadis maupun ilmu hadis, yang kini menemukan polanya dan bentuk pemasarannya yang jelas di masyarakat.Dan imbas positifiiya, bermunculan pula buku-buku ilmu hadits yang ditulis oleh anak bangsa ini.

Namun harus dicatat, adanya gagasan penerjemahan kitab-kitab Hadis maupun Ilmu Hadis maupun kitab keagamaan Islam yang lainnya, diduga kuat bahwa para penggagasnya adalah kaum modernis atau sekurang-kurangnya mereka yang terimbas dan menerima adanya gagasan modernisasi pemikiran keislaman tersebut, walupun sesungguhnya mereka bukan yang terhisab secararesmi dari barisan modernis Islam di Indonesia. Karena kultur penerjemahan kitab-kitab keagamaan Islam itu, seperti pemberian syarah kitab yang sedang dipelajari, yang berlangsung dan menjadi ciri khas Islam Tradisional adalah dengan memakai Arab-Melayu atau Arab-Jawi, dalam sebutan orangn Malaysia.

\section{DAFTRA PUSTAKA}

A. Hassan, Risalah Al-Qur'an Dan Al-Sunnah (Bangil: Penerbitan Pesantren Persatuan Islam, 1972)

Aen, Nurol, 'Perkembangan Literarur Hadis Di Indonesia', Majalah Istiqra No. 6/th.VI/Juli-Desembe, December 1992

Al-Tirmisi, Muhammad Mahfudz, Manhaj Dzaw Al-Nazhar (Beirut: Darr al-Fikr, 1981)

Ash-Shiddieqy, M. Hasbi, 2002 Mutiara Hadits (Jakarta: Bulan Bintang, 1954)

Azra, Azyumardi, Jaringan Ulama Timur Tengah Dalam Keplauan Nusantara Abad XVII Dan XVIII, Melacak Akar-Akar Pembaruan Dan Pemikiran Islam Di Indonesia (Bandung: Mizan, 1995)

Bahreisy, Salim, Himpunan Hadis Shahih Bukhari (surabaya: Al-Ikhlash, 1981)

—, Terjemahan Al-Lu'lu Wa Marjan (surabaya: PT Bina Ilmu, 1981)

- Terjemhan Riyadh Al-Shalihin (Bandung: al-Ma'arif, 1983)

Fathurrahman, Hadits-Hadits Tentang Peradilan Agama (Jakarta: Bulan Bintang, 1977)

Fijper, G.F., Baberapa Studi Tentang Sejarah Islam Di Indonesia 1900-1950, trans. by Tudjimah dan Yessy'Agustin (Jakarta: UI Press, 1984)

Hadzik, Muhammad Ishom, 'No Title', H. $U$. Republika

Hamidy, Zainuddin, Terjemahan Shahih Bukhari (Jakarta: Wijaya, 1983)

Hamka, Pengaruh Muhammad Abduh Di Indonesia (Jakarta: Tintamas, 1961)

Harun, Daud Rasyid, Juhud Ulama Indonisiya Fi Al-Sunnah, Risalah Muqodimah Linail Darajat Al-Daktarah Fi Al-Syari at AlIslamiyya (kairo: Jami'ah al-Qahirah, 1996)

Hasan, A., Terjemahan Bulugh Al-Maram (Bandung: CV. Diponegoro, 1983)

Hassan, A., Soal Jawab Jilid I-III (Bandung: CV. Diponegoro, 1983)

Koho, A. Yazid Qasim, Kumpulan Hadits Dha' if Dan Palsu (surabaya: PT Bina Ilmu)

Madjid, Nurchalis, Khazanah Inlelaktual Islam (Jakaarta: Bulan Bintang, 1984)

Muhammad, Mawardi, Jawahir Al-Hadits 
(Padang Panjang: Pustaka Sa'diyah, 1950)

Muhammadiyyah, PP, Himpunan Putusan Takhrij 1929-1972 (Yogyakarta)

Noer, Deliar, Gerakan Islam Kontemporer Di Indonesia (Jakarta: Pustaka Firdaus, 1994)

_ Gerakan Modern Islam Di Indonesia 1900-I942 (Jakarta: LP3ES, 1980)

Razaq, A, Terjemahan Shahih Muslim (Jakarta: Pustaka al-Husna, 1978)

Sejarah Islam Di Minangkabau (Sumatera Barat) (Jakarta: Tintamas, 1961)

Steennbrink, Karel A., Pesantren Madrasah Sekolah Pendidikan Islam Dalam Kurun
Modern (Jakarta: LP3ES, 1994)

Stoddard, L., Dunia Baru Islam, trans. by H. M. Muljadi Djojomartono (Jakaarta: Panitia Penerbit, 1966)

Yunus, Mahmud, Sejarah Pendidikan Islam Di Indonesia (Jakarta: Mutiara, 1979)

Zuhri, M., Terjemahan Al-Hadits Al-Qudsiyah (Semarang: CV. Toha Putra, 1981) 